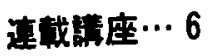

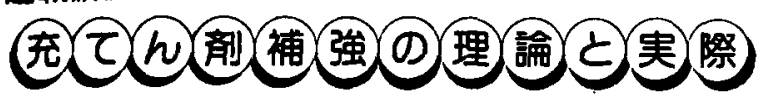

\title{
カーボンブラックの基本特性以外 の特性とパーフォーマンス
}

仲田俊夫

\section{1.はじめに}

ゴム補強に係わるカーボンブラックの基本特性は，比 表面積(粒子径)，ストラクチャー(凝集性状)，表面の物 理化学的性質に絞られるが，このほかに加熱減量，灰 分，トルエン着色透過度(Stain 物質)，子るい残分及び 造粒特性がゴム配合物性に影響する。特に造粒性状(以 下ペレット性状ともいう)は，カーボンブラックのハン ドリングに関俰する品位的特性に止まらずゴムの混練加 工性, 分散性に影響し, 基本特性に優れた場合でもペレ ット性状如何では最終製品の性能を充分発揮できない.

ここでは, ペレットの硬さ, 粒度などの特性とゴム混 練举動, 分散珄の関係について若干の寒験例を紹介しつ つ述べる.

\section{2. カーボンブラックのゴム混練举動}

\section{1 ゴムへの混練現象}

カーボンブラックの密閉系混合機におけるゴムとの混 合状態は，その過程の消費電力の時間推移から間接的に 知ることができる゙.カーボンブラックをミキサーでゴ ムに練り込む際の消費電力の変化は，一般に図 1 で説明 される. 図中, a 点でゴムにカーボンブラックを添加し ラムを压入すると，消費電力は急上昇しb点でピーク に達するが，次いで减少し， c 点に至り，再度電力の上 昇があってd点で第2のピークを経たのち，緩やかに 减衰する.これらの現象は，前段の初期混合過程と後段 の分散拡散期にわけられるが，a〜c 領域が前段で， c 以 降が分散拡散期に該当しよう，一般には，カーボンブラ ックを投入後，d点に至る時間をインコーポレーション タイムあるいは BIT (Black Incorporation Time)と呼び, カーボンブラックとゴムの一体化の目安とされる. これらの混合過程を若干詳しく観察すると，a〜 b 過 程ではゴムが細粒化し表面がカーボンブラック粉で塗さ れた状態にあり，b点では更に細粒化しカーボンブラッ クをとり込んだストックがフレーク状に圧着一体化し脆 弱な組緎を形成する.これらは以後のせん断力に負けて 壞れ，消費電力の低下を伴って c 点に達する，c点では ゴムは極めて硬質のブロックとなり，カーボンブラック はゴム中にとり込まれ污染性はない，これらの混練ゴム は練り進むと粘着性を增し，d点近辺では表面の艷に富

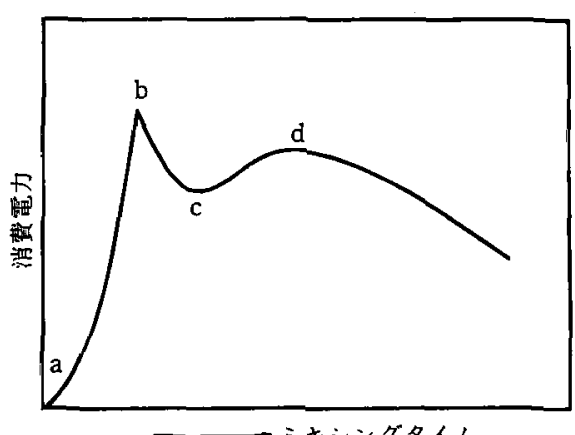

図 1 ゴムに対するカーボンブラック混練時の消費 電力推移 ${ }^{2)}$

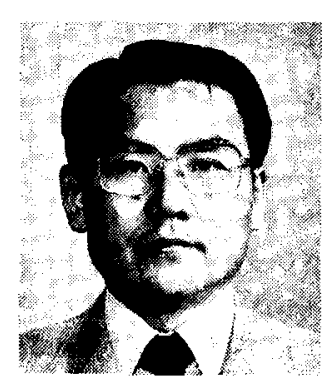

*東海カーボン侏知多研究所 ( ₹470-23 愛知県知多郡 武豊町字 5 号地 1 番) 副所 長. 昭和36年東京理科大学 卒業. 同年同社入社.52年 フランス CMRS Laboratoire Marcel Mathieu (Orléans) 滞在，炭素微構 造の高分解能電䫓解析につ き Dr. A Oberlin k師事。 研究第二課長を䅅て60年よ り現職。〈趣味〉絵画製賞 
んだストックとして完成され，カーボンブラックの分散

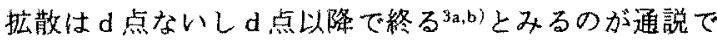
ある。

分散現象は，マク口的には末分散凝集塊の崩填的搪 散，セミミクロ的にはカーボンブラックアグロメレート 空隐へのゴム浸入による解れ应散，更にミクロにはアグ リゲート個々のゴム吸蔵的による複合一体化などを包括 したものと考えられる。

\section{2 ゴム混鄱における影則因子}

カーボンブラックのゴム泥練学動は, 配合量, ゴムの 種類，注練条件(バッ千容樍，ロータ一回転数，ラム㞋 など)で䇅わるが，これらを一定とした場合，カーボン ブラックの比琵面積，ストラクチャー及びペレットの性 状などの影響在強くうける。

図 2 に，代表的八イストラクチャーブラックである N-285を各種のゴムに混練した場合のバンバリーミキ サ一消費電力推移を比較対比した．NRでは；カーボン ブラックは比較的早くゴム上の浘和がすすむが, SBR ではゴム相とカーボンブラックの刨染みに手間どり，混 合初期の消費電力の立ち上がりが大幅に避れる様子がう かがえる。ただし油展 SBR はNR 同様初期の混和が良 好で, 最大ピークに達する時間も早く混練性に榎れてい ることが判る。

図 3 は混練の際のラム压力の影響であるが，NR 及で SBR 1500 上もにラム設定圧力の上昇に伴い，混入時間 の短維が顥著である。なお，これらの影響はハイストラ クチャーブラック(N285)で特に大きく，低ストラタチ ヤーブラック(N326)では比較的小さい。

図4に，SBR 1500 でN285を変量配合した場合の消

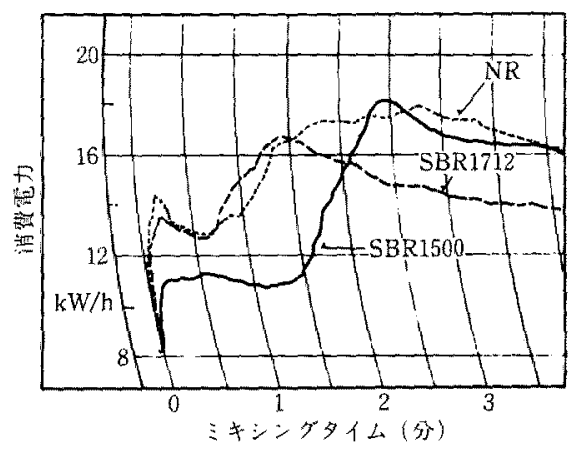

図 2 各種ゴムでのカーボンブラック混練時の消費 電力曲線〔B型バンバリーミキサー，バッチ 容積 $1.05 l$, ラム压 $5.0 \mathrm{kgf} / \mathrm{cm}^{2}$ ，ローター $70 \mathrm{rpm}]$

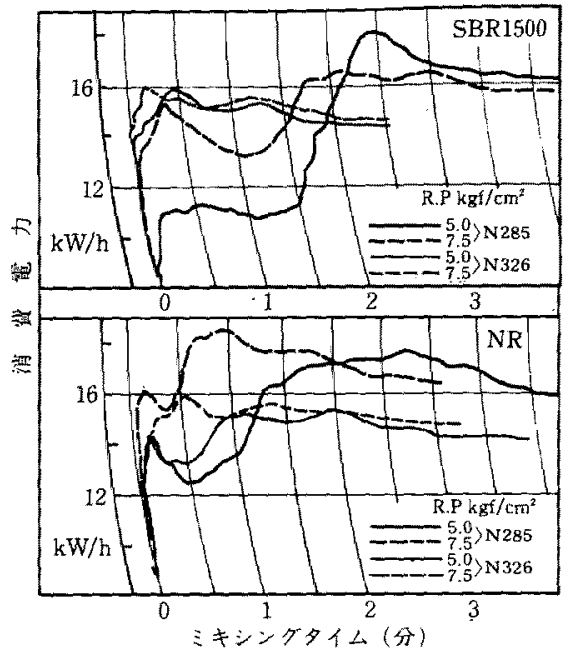

図3ラム民のミキシングに及ぼす影響〔B型バン バリーミキサー，バッチ容積 $1.05 l$ ，ロータ - 70 rpm]

費電力推移を示与，配合量の增加に伴って混練初期の立 ち上りと最大ピータへの到達時間に碰れがみられ，特に 30〜40 PHR 以上でこの傾向が强まる.

カーボンブラックの基本特性でゴム混練挙動に直接影 留するものは，粒子径(比表面積)及びストラクチャ一 (空隌容積)である，図 5 に，各種カーボンブラックの SBR 1500 配合による消殞電力推移を示すが, 初期混合 は難分散性の䍊粒品種 $\mathrm{N} 110\left(\mathrm{~N}_{2} \mathrm{SA} 140 \mathrm{~m}^{3} / \mathrm{g}\right)$ でむしろ 速く，稙子の粗い $\mathrm{N} 550\left(\mathrm{~N}_{2} \mathrm{SA} 45 \mathrm{~m}^{2} / \mathrm{g}\right)$ で遅延する。力 一ボンブラックストラクチャーは，本䓄に䪱いてアグリ ゲートの大きさ，形態に関俰するが，ゴムとの很練性を

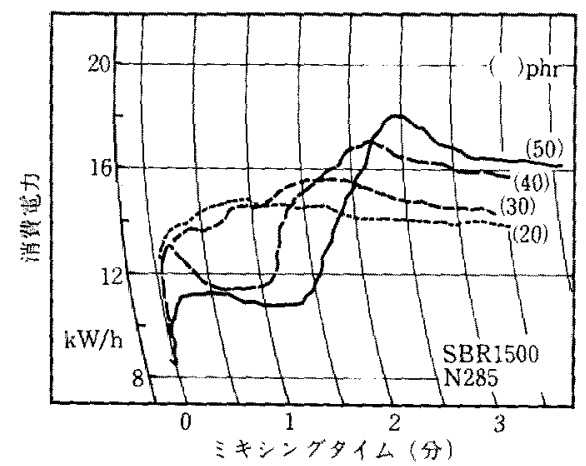

図4 カーボンブラック配合量のミキシングに及ぼ 才颜響〔B型バンバリーミキサー,バッチ容 皘 $1.05 l$ ， ラム王 $5.0 \mathrm{kgf} / \mathrm{cm}^{2}$, 口ーター70 rpm] 
考えるうえで圧樎最密充てんでの空㩐の程度と関係うけ るのが適切であろう．24,000 PSI (165.5 MPa)加圧下で の比空隐量すなわち 24M4DBP 吸収量とBIT(インコー ポレーションタイム)の関係を図 6 に引用する5!. 図中, 比表面積ほか若干別の要因の交絡も予想されるが良好な 相関が認められ，24M4DBP 值の增加に伴 う混入時間の 避机が明らかである。

次にカーボンブラックのペレットの影響であるが，こ れらの特性はペレットの硬さとゴム分散性の係わりにお いて注目されてきた。しかし，ゴム混練加工性に対して むペレットの大きさ，同分布，微粉それぞれの係わりが あって大いに留意する必要がある，N285のペレットを 子るいで $>1,000 \mu \mathrm{m}, 1,000 \mu \mathrm{m} \sim 500 \mu \mathrm{m}, 500 \mu \mathrm{m} \sim 149$ $\mu \mathrm{m}, 149 \mu \mathrm{m}$ パス(粉)それぞれに分級し，各粒度别に B 型バンバリーでSBR 1500 に練り込んだ場合の消費電 力推移を図 7 に示す. ペレットの大きさで混合挙動にか なりの差異があり，消費電力の立ち上りに至るインダタ ションタイム及び最大ピークへの到達時間をもとに混練 速度を位置づけると，1,000 $\mu \mathrm{m}$ 上の粗大ペレットが最 も速く, $1,000 \mu \mathrm{m} \sim 500 \mu \mathrm{m}$ 分級粒が最も遅延する。同 様の実験をN326 でおこなった場合もほぼ同様の結果と なるが，本来ゴムへの食い込みのよい低ストラクチャー ブラックではハイストラクチャーブラックほど顕著では ない.

一方，カーボンブラックのペレットは実際に粒度分布 を持ら、ゴムへの混練性をこれらの状態を前提に考える 必要があるが，特に問題となるのは微粉の影響である。

$1,000 \mu \mathrm{m} \sim 500 \mu \mathrm{m}$ の分别粒に微粉を混入した場合の 混練挙動を図 8 に示す. N285の場合, 微粉の增加に伴

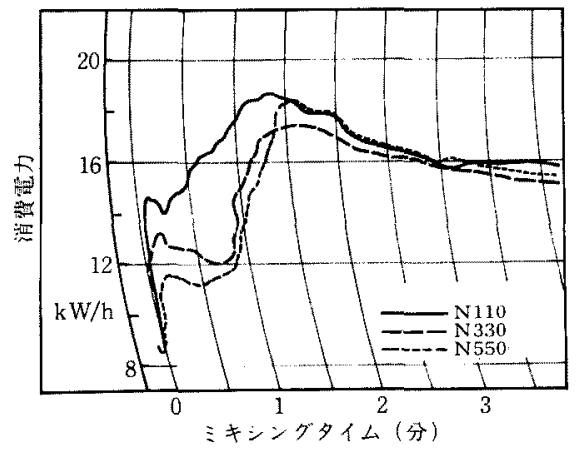

図 5 各種カーボンブラックのSBR 1500 配合消費 電力曲線〔B 型バンバリーミキサー，バッチ 容積 $1.05 l$, ラム压 $5.0 \mathrm{kgf} / \mathrm{cm}^{2}$, ローター $70 \mathrm{rpm}]$

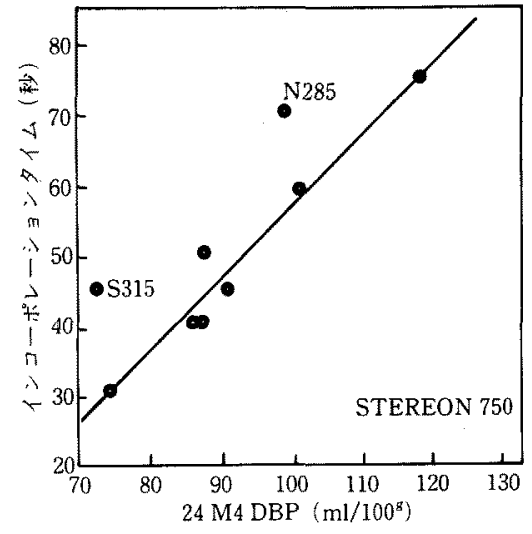

図 6 24M4DBP とインコーポレーションレイム5)

つて電力異荷の立ち上りが遅れ，最大ピークに澾する時 間も途延する．興味深いのは微粉単味の挙動で，粒と共 存する場合より混練性はむしろ優れた傾向を示す。 N326では比較系相互の差が維少しているものの，ラム 加圧後の消費電力の立ち上りはむしろ微粉の增加ととも に早まる逆の傾向がみられる、したがってこれら微粉の 影響についてはストラクチャーレベル，比表面積などミ クロコロイダル特性との係わりで眺める必要があろう。

カーボンブラックのペレット硬さとゴム混練性につい て，プラストコーダーによる奏験結果を図 $9^{6}$ に示す. ペレット硬度の増加に伴いBIT が短縮されるが，この 関係はペレットサイズの影響をうけ，小粒ほど相関が緊 密となる、 $1,500 \mu \mathrm{m}$ 近辺ないし, それ以上の粗大ペレ ットでは硬さの影響はほとんどなくなる。

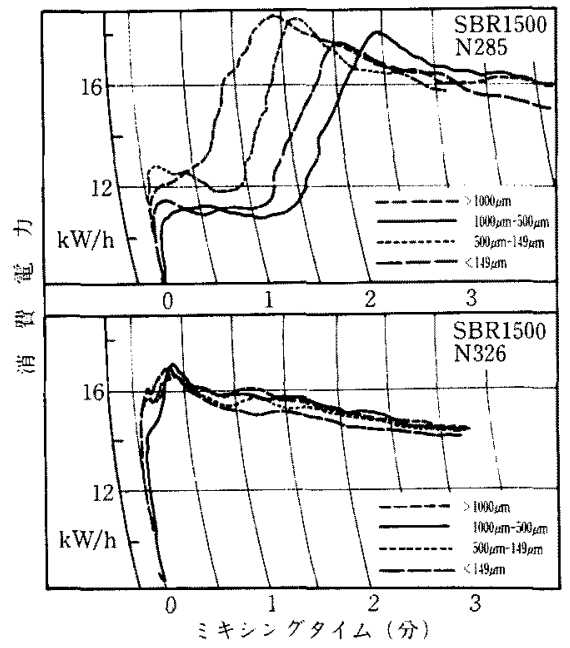

図7ペレットサイズのミキシングに及ぼす影響 〔B型バンバリーミキ甘ー，バッチ容積 1.05 l, ローター $70 \mathrm{rpm}$ ] 


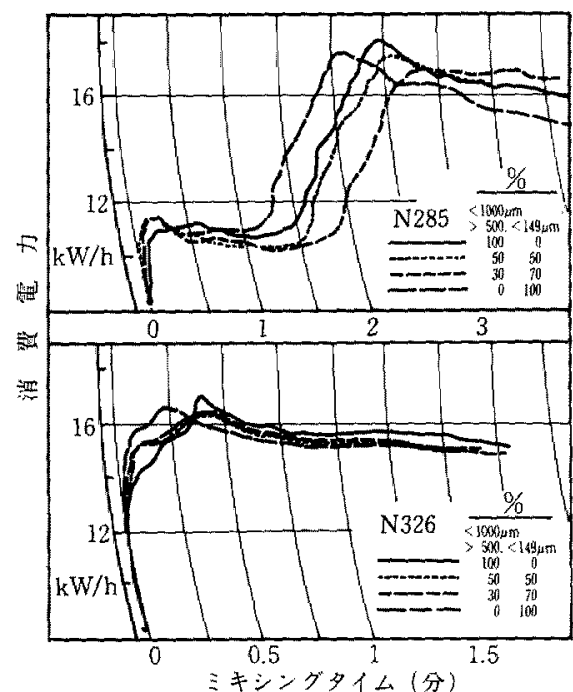

図 8 ペレット $/ 149 \mu \mathrm{m}$ パス微粉変量混合によるミ キシング挙動 [B型バンバリーミキサー,バ ッチ容皘 $1.05 l$, ローター70 rpm, SBR $1500]$

カーボンブラックペレットのゴム混練に影響する特性 として，他にかさ密度があるが，これらはカーボンブラ ックの基本特性(比表面樍，吸油量)，ペレットサイズ， 硬さなどを包括したものであり，独立した要因上して扱 いにくい面がある。

\section{3 ゴムへの分散と影彎因子}

ゴム中でのカーボンブラックの分散搪散はいわば“ほ ぐれ”の現象であり，“ほぐれ”が円滑にすすむために はアグロメレート空隌へのゴムの浸入が前提となる。こ 机らの分散現象を基本的に理解するうえで，図102!及び Mekelveyの式”引引用する。

ゴム中に分散したカーボンブラックのアグロメレート にせん断力が加わると，これを構成しているアグリゲー

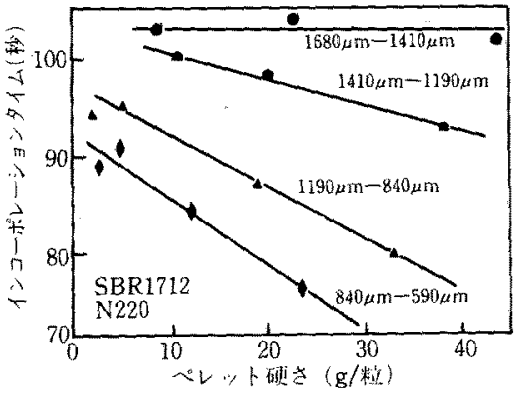

図 9 ペレット硬さとインコーポレーションタイ $\Delta{ }^{6}$ )
ト個々に流動铑引力が動いて，弱い凝集部分を引き離す 作用が生しる。るの度合はストークスの法則が適用で きアアグロメレートの有效径，ゴムマトリックスの粘 度，せん断速度に依存する，なお，この力はアグりゲー 卜同士の㠜集力に対抗するものて，相互の力のバランス 関係仕図10のモデルから次式で表わすことができる。

$$
K=6 \pi \operatorname{Re} \mu \dot{r} / C
$$

$K:$ 分散ファクター $\mu$ : マトリックス粘度

分散に漫孔た吸油量の高い，ないしは比表面積の小さ いカーボンブラックでは，Reが大きく凝集力Cは相対 的に小さくなる，難分散性の吸油冝の低い，比表面皘の 大きい品種では，Reは小さく凝集力がこれに勝るもの と理解できる、特に低ストラクチャ一品種では，アグリ ゲートの形が closed claster型で，相互の凝集力も強く， 低いせん断応力上相俟って分散が充分進行しないものと 考えられる、なお，ゴム中のカーボンブラックリッチな 凝集物(部分的に生じた高充てん部分)，硬質ペレットの 末分散塊(カーボンブラックの圧縮凝集物)などでは流動 毫引力の作用が隇衰するかあるいはアグリゲートの㠜集 力が極度に強まることになり，ほぼ亘久的に分散不良状 態を引き起す。

ゴム混練過程で段階的に採取したゴム中のカーボンブ ラックの量, 回收ブラックの吸油䑁変化を調べ，混練過 程でのカーボンブラックの分散推移を追跡した奏験例を 次に述ぶる。

B 型バンバリーミキサーT゙ SBR 1500 にN285, N326 各々を練り込み，図11で示す消費電力チャート所定位置 (A〜E)で排出した各コンパウンドからカーボンブラッ クを回收し，混入量及び吸油量(JIS B 法)を測定した。 練りゴムからのカーボンブラックの回収は，減圧熱分解 法（40 Torr 以下， $480^{\circ} \mathrm{C} \times 20$ 分)によるが，吸油量測定 の祭の雀点は明瞭であり，相対比較は充分可能と判断し た，表 1 K，各混練ステージでのカーボン回収量, 吸油

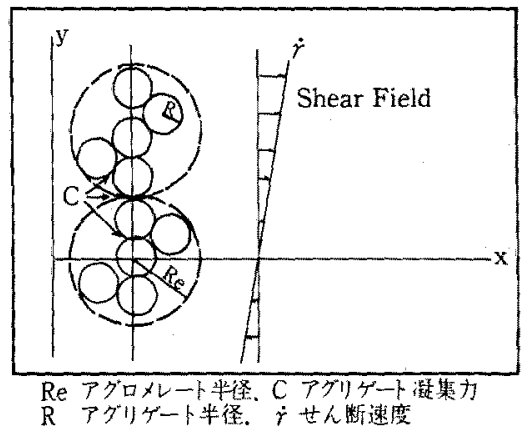

図10 カーボンブラックのゴム分散モデル2) 
量を示す. N285 では，カーボンブラックの回収量は C 点でほぼ一定となるが，吸油量は C 点より遅れ D点付 近で平衡に達する。これをアグロメレートの“ほぐれ” 限界とみると，分散拡散はD点前後まで継続したもの と考えられる．低ストラクチャー品種のN326では，吸 油壆の相対変化は C 点以前に一定となっているが，力 一ボンブラックの回収量は D 点以降で漸く平衡に達す る傾向にあり，初期におけるゴムへの混練の容易さとは 逋に，ゴム相への移行の難かしさを示している。これら の一部はゴム中一移行後も強固な凝集物を形つくくり，更 に練りすすんでも古分な分散㹡散は期待できない。

\section{3. 造粒ペレット性状とゴム混練性}

\section{1 カーボンブラックの造粒}

カーボンブラックの造粒は，国内では湿式法が主で, 蛑旋状にピンを植え込んだ回転シャフトを内蔵するドラ 么型造粒機内で水と激しくかくはん混合することから調 製される。ペレットの大きさ，分布，硬さ，加さ密度 は，ピンの周速，カーボンブラックへの水の添加割合， 添加方法などによってコントロールされる。ペレットサ

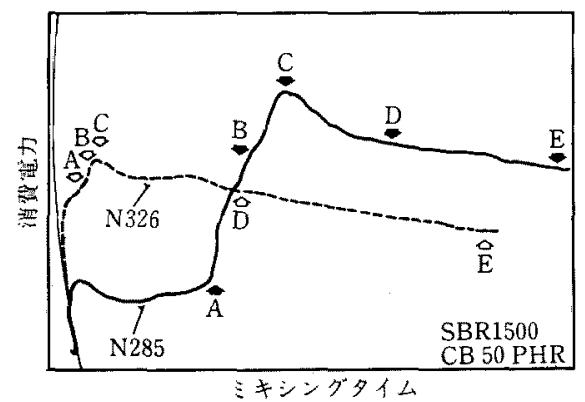

図11 カーボンブラック混練過程での各バッチ排出 位置
イズは，一般に 2,000 $\mu \mathrm{m} \sim 149 \mu \mathrm{m}(149 \mu \mathrm{m}$ 下は微粉と して扱う)にわたって分布しており，バルクハンドリン グの際のペレットの流動性(図12)，耐破壞性に適した $1,000 \mu \mathrm{m} \sim 500 \mu \mathrm{m}$ の粒径域を中心に工程を管理する。 また，ペレットの硬さ》は，ゴム分散と直接係わり，造 粒工程で最も隡しい管理下におかれているが，破粒防止 と分散性のバランスを考虑して普通 $20 \mathrm{~g} /$ 粒以下に収め られる。しかし，IIRなど低粘度の難分散性ポリマーを 対象とする品種では, ペレット個々の硬さの上限もチェ ックの対象となり，最大 $15 \mathrm{~g} /$ 粒前後の出現頻度を数\% 以下に規制する場合むある。ペレット硬さの分布例を図 13に示すが，平均値が低いほど分布はシャープで，極端 に硬い粒を含む他険は少なくなる。

\section{2 コム湿練性に関する考察}

カーボンブラックのゴム混練性に及ぼす影響を総括す ると, (1) $1,000 \mu \mathrm{m}$ 近傍以上の粗大な粒は練り初期のゴ ムへの食い込みがよく混合も早い，(可 $1,000 \mu \mathrm{m} \sim 500 \mu$ m 前啳のペレットではゴムへの食い込みが最も悪く， 混合が遅い，け㤷ットと微粉の共存は混練性が低下す るが，微粉のみでは逆にゴムへの食い込み，混練性は增 す(高ストラクチャー品種)，(たペレット硬さが増すと BIT が短縮する，などの特徴が挙げられる。

イ特徴については，ペレット相互の摩擦力の増加に 関係寸る，図14は，各分級粒での粒度と内部摩摖係数を 対比したもので，149 $\mu \mathrm{m}$ パス微粉及び粗大粒子おのお のの内部摩擦が相対的に大きい状況を示しており， $1,000 \mu \mathrm{m}$ 近傍以上の大粒域ではミキサーへ投入直後に ペレットへの負荷がかかりやすく、ゴムへの食い込み， 混合が早まるものと推定できる，粗大なペレットの内部 構造は脆弱であり，破砕しやすい，図15に，1,000 $\mu \mathrm{m}$ 近傍及び $1,680 \mu \mathrm{m}$ 上の粗大粒各断面の SEM 観察例を

表 1 ミキシング過程でのカーボンブラックの混入率及び回収カーボンブラックの昅油量の変化

\begin{tabular}{|c|c|c|c|c|c|c|}
\hline \multirow[b]{2}{*}{ ステージ品種 } & \multicolumn{2}{|c|}{$\begin{array}{l}\text { 排出時間 (カーボンブラック } \\
\text { 投入後秒) }\end{array}$} & \multicolumn{2}{|c|}{$\begin{array}{l}\text { 採取バッチのカーボンブラッ } \\
\text { ク混入率 }(\%)^{*_{1}}\end{array}$} & \multicolumn{2}{|c|}{$\begin{array}{l}\text { 回収カーボンブラックの吸油量 } \\
(\mathrm{JISB} \mathrm{ml} / 100 \mathrm{~g}){ }^{* 2}\end{array}$} \\
\hline & N285 & N326 & N285 & N326 & N285 & N326 \\
\hline A & 90 & 12 & 32.0 & 24.8 & 135 & 98 \\
\hline $\mathrm{B}$ & 105 & 18 & 33.7 & 32.0 & 132 & 93 \\
\hline $\mathrm{C}$ & 138 & 25 & 34.1 & 33.6 & 129 & 93 \\
\hline $\mathrm{D}$ & 196 & 105 & 34.2 & 34.1 & 125 & 93 \\
\hline $\mathrm{E}$ & 360 & 240 & 34.3 & 34.3 & 126 & 94 \\
\hline
\end{tabular}

注1) Recipe: SBRI500, 100/カーボンブラック，50 PHR(配合率33.3\%)

2）配合前の吸油量 $\mathrm{N} 285 / 140 \mathrm{ml} / 100 \mathrm{~g}, \mathrm{~N} 326 / 84 \mathrm{ml} / 100 \mathrm{~g}$

練り条件；B 型バンバリ・ミキサ, バッチ容量 1.051 ラム圧 $5.0 \mathrm{kgt} / \mathrm{cm}^{2}$ ローター70 $\mathrm{rpm}$, 混練開始温度 $80^{\circ} \mathrm{C}$ 


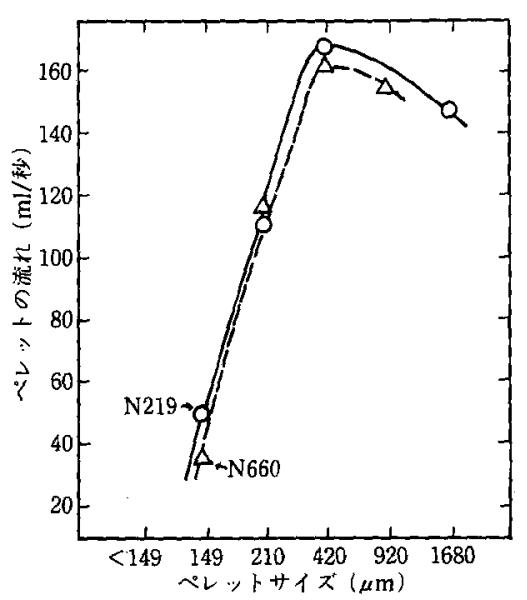

図12 ペレットサイズと流動性(ロウトによる流下 テスト)

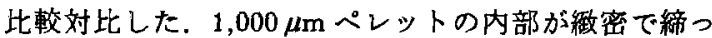
た組織であるのに奶し，1,680 $\mathrm{m}$ のペレットでは内部 が断層化しており，極めて脆弱な楧造となっている.こ の上うなペレットはミキサー内で容易に壊れ，軟質の細 粒, 粉となるが, 高以内部摩擦の相乘効果も加わりゴム への混入が加速されるものと考える.

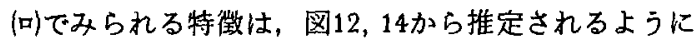
$1,000 \mu \mathrm{m} \sim 500 \mu \mathrm{m}$ 領域のペレットが流動性に富み, 低 い摩擦抵抗に加えて緻密な内部組織によるペレットの權 れにくい状況が重なった結果と考えられる.

叭昜合，微粉のみの鼬練性はともかく，ペレットと 粉が共存する系の举動は複雑とみられる，ペレット内の 粉の存在は流動性を低下させ，含まれる微粉の割合が $30 \%$ 前後を上回ると內部摩擦が急激に增加する、これら はむしろ低ストラクチャー品種でみられるようにゴムへ の食い込みやすさに有利な要素となるが，高ストラクチ ヤ一品種でみられる混入の遅れは，粉とペレット共存下 での粒の破塄举動など異質の現象によるものと考えたい.

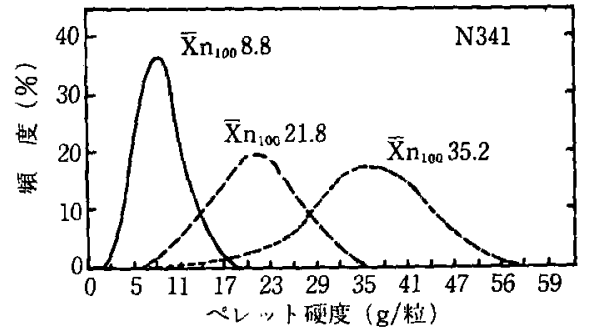

図13ペレット硬度 $(1,000 \mu \mathrm{m})$ の分布

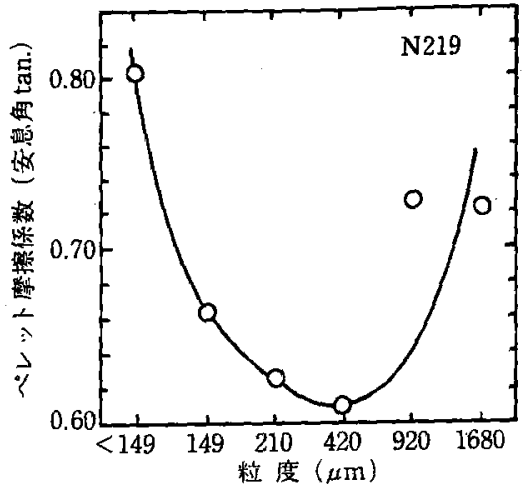

図14 ペレットの大きさと流動内部摩擦係数の関俰

仁の特徵であるペレット硬さの影響は，すでに述べた ようにペレットサイズと交絡し，硬いペレットでも破砕 しやすい粗大粒域ではゴム混練性との相関は薄れる。へ レット硬さの増加によるBITの短縮は, 砕破粒が充分 に解れない段階にゴムにとり込をれ，カーボンブラック の実犋的配合量が減少した結果との見方もできる。

\section{4. カーボンブラックの圧縮凝集挙動と分敬性}

\section{1 ペレット硬さと分散性}

カーボンブラックを压緶すると凝集し，加えた力の程 度に応じて最密充てん状態を形成する，この度合が強ま るとアグロメレートの空隙が減少ないしスリット化し，

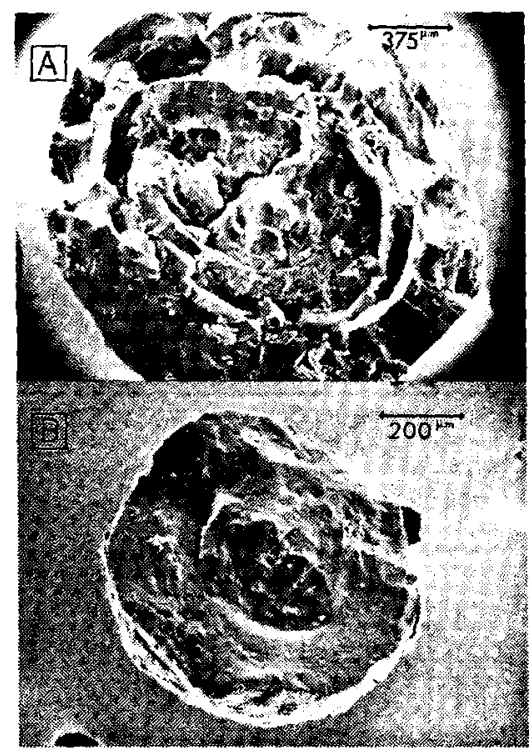

A. $>1680 \mu \mathrm{m} \quad$ B. $>500 \mu \mathrm{m},<1000 \mu \mathrm{m}$

図15 カーボンブラックペレット破断面の走督電子 顥微鏡写真 


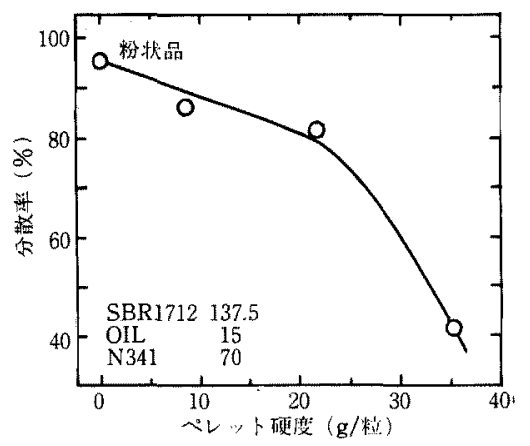

図16 ペレット硬度と分散率

粒間内部へのゴムの浸入搪散がす寸みにくくなるために 分散が妨げられる.カーボンブラックのペレット硬さ は，造粒機內でのせん断圧縮による凝集の程度を反映し たものであり，カーボンブラックの凝集性と分散を関係 ゔける身近な例である。

図16k，N341でのペレット硬さと分散の関係を示す が，ペレット硬さが $20 \mathrm{~g} /$ 粒近辽を起える上急激な分散 率の低下が生じる状況がよくわかる，なお，硬い粒によ って生じる未分散塊はいずれも円みをもっており，練り すすんでも解れにくい状態にある.

\section{2 カーボンブラックの压縮凝集性と分散}

N285(易分散性)，N326(難分散性）及び代表的市販 銘柄であるN220，N330について，繰り返し加圧後の成 形ケーキの破砕強度と分散の関係を求めた実験例を図17 に示す、図中，カッコ内に圧縮かさ密度を併記したが，

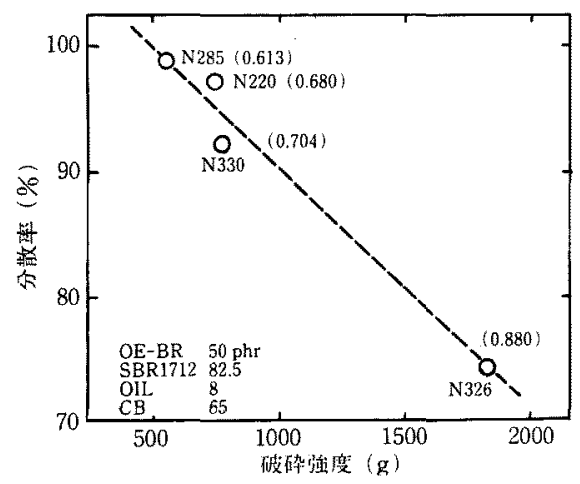

図17 王縮凝集塊の砕破強度と分散率の関係 〔砕破強度の求め方: 250 500 $\mu \mathrm{m}$ の乾燥ぺ

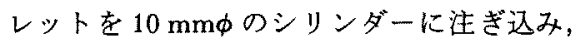
$680 \mathrm{kgf} / \mathrm{cm}^{2}$ で加圧，とりだしたケーキを解 し同様の操作で計 5 回の圧縮を繰り返す. 5 回目の成型ケーキを台科りの上でへラを用い て压し，砕破に至る強度を科の指標としてよ みとる.丁

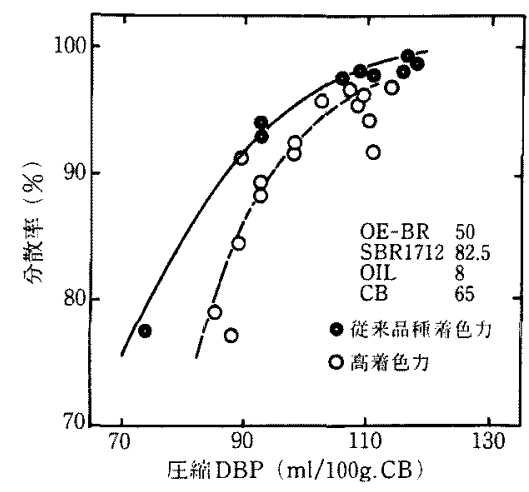

図18 压縮 DBP(24M3) と分散率の関係

破砕強度の高い凝集力の強い品種では, かさ密度も顕著 に高く，分散も大輻に劣っている。

压縮凝集性はカーボンブラックの吸油量に依存する が, カーボンブラックの着色力(アダリゲートサイズが 小さく分布の狭い特徴に対応)にも関係する，吸油量に 大差がなくとも，高着色力を特徴とする新品種が分散性 に少ることは経験的に知られているが，これはミクロコ ロイダル特性にもとつく凝集挙動の影響によると考えら れる. 図18に，カーボンブラックの圧縮後の吸油量と分 散率の関係示寸，分散は死縮凝集性の小さい高王維 DBP 值に対応して高まるが，同等の圧維 DBP 值では高 着色力グループの分散が低位にずれ，この傾向は低スト ラクチャー領域で一層顕著となる。

\section{5.むすび}

カーボンブラックのゴム性能に係わるミクロコロイダ ル特性以外の重要なものとして，ゴム混練性，分散加工 性を採り挙げ，現象及び影響因子をクローズアップしつ つ,カーボンブラックの造粒特性, 凝集挙動との係わり について述べた.

カーボンブラックのペレットは，バルクハンドリング の普及からますます轡しい管理下にあるが，タンクロー リーへの皘載, 積み下るし, 輸送, 受け入れ前後のタン クでの貯蔵, 練り工程での移送など粒の劣化要因に事欠 かず, 適正粒の維持については日常, 製造工程で腐心し ている.

これらペレットの性状とゴム混練加工性との基本的係 わりを知ることは，ゴム韲練工程の安定化など害際面で 有用と信ずる.

一方，補強性に優れたカーボンブラックはアグリゲー トの大きさ，形状などミクロコロイダル的特徴を背景と 
するが，背反的に分散加工性を損うなどのジレンマをも つ.ここでは，その本質とみられるカーボンブラックの 凝集举動在堀り下げることから分散加工面で何らかの改 善の糸口がつかかわれ梳と期待している.

カーボンブラックのゴム混練性, 分散性人の関心は, 最近ますます高まりつつあり，分散性改善を特徽とする 新品種ブラックの抬頭》など新たな動きもある。ざム混 練性，分散現象の解明はそのとり組みも多様であり，解 説て9など相当数にのぼるが, 最近ではよりミクロな視 点からの理論的究明10)们屯すすみその成果が期待される.

本稿は日本ゴム協会，第16回ゴム技術シンポジウム “黑と白”充てん剂補强の理諭と実際( 58.10 .28 , 於東京) 觏演内容による。

\section{荅考文献}

1) Studebaker, M. L., Beatty, J. R.: Rubber Age., 108 No. $521(1976)$
2) Dizon, E. S.: Rubber Chem. \& Techynol., 4912 (1976)

3) a Tokita, N., Plaskin, I.: ibid., 461166 (1973)

b Palmager, H.: ibid., 48462 (1975)

4) Medalia, A. I.: J. Colloid Interf. Sci., 32115 (1970)

5) Studebaker, M. L., Beatty, J. R.: Rubber Agey., 108 No. 621 (1976)

6) Atokins, J. H., Boonstra, B. B.: Rubber Chem. \& Technol., 391081 (1966)

7）JIS K 6221(1978)“ゴム用カーボンブラック試虰方 法"

8) West, J. R., Lovett, L. L., Keach, C. B., Presented at a meeting of Rubber Division A.C.S., oct $23 \sim 26$ (1984)

9) 占部誠亮：“ポリマーダイジェスト”34 Nol 60 (1982)

10）志賀周二郎，山田秀昭，吉田元信，市川三郎，日 笠 忠:日本ゴム協会研究発表講演要旨，67(1983)

11) Nakajima, N., Harrenn, E. R.: Rubber Chem \& Technol. 56 197(1983)

\section{有機物のメカノケミストリー}

総合出版社刊 A5 版 185面 3,200円

\section{久保輝一郎 渚}

ゴム関係者にとって，メカノケミストリーといえ ば，W.F、Watsonの素練り以来，身近なものと考 えられている。また，メカノケミストリーという と，ゴム以外でもポリマーが主体と考えられていた が，この著書では著者の経厢から，無機物と有㙨物 の相互作用とか，医薬品のメカノケミストリーなど と、妄い範围でメカノケミストリーを採り举げてい るのが特舞といえる。

内容を羅列してみると，1)化学的↔機械的工 ネルギーの変换，屰）ポリマーのメカノケミカル現

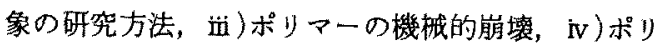
マーの崩壊にみられる諸物性，v)ポリマーの崩㿆 に影響する諸因子，iv)メ力ノケミカル合成，viii)メ カノケミカルに起こる哭機物一有機物の相互作用。
、並)医薬品とメカノケミストリーとなっており，屰） で恃古川，山下，箕浦，後藤の諸先生の找仕事も紹 介されている，またvii门では，無機充てん斉の内容 を含み，ゴム技術者にとっても応用可能な内容であ り，唡)は興味をもつて読むことができる。

以上のように, 従来のどちらかというと化学的に 片寄ったメカノケミカルとはややニュアンスが異な り，基礎的な内容を多く含むので，ゴム技術者がゴ ム加工という害用的な面からみるとメカノケミカル という範ちゅうにしばられているのでもう一歩とい う不満が残るかもしれないが，読み方によっては， 研究者にとっても技術者にとっても，多くのヒント が得られる好著ということができよう。

(大内新興化学工紫(侏) 渡辺 隆) 